\title{
Insights from an Entrepreneur: Interview with Dr. Sushil Bhatia, Founder of JMD
}

\author{
Vinnie Jauhari \\ Institute for International Management and Technology, Gurgaon, India
}

\begin{abstract}
This article is presented in the form of an interview with Dr. Sushil Bhatia conducted by Dr. Vinnie Jauhari. This interview with Dr. Sushil Bhatia, President and CEO of JMD, an organization based in USA provides insights into how new products are developed. The interview also documents challenges faced in new product development. The discussion with Dr Bhatia also involves discussing the challenges in developing new technologies and difficulties associated with the process of commercialization. The lessons learnt therein would be valuable for both practitioners and academics.
\end{abstract}

\section{INTRODUCTION}

Dr. Bhatia combines in him a passion for achievement and ability to work hard. This combined with a dynamic external environment has resulted in meaningful contributions to the society. This interview provides insights into how entrepreneurs can contribute meaningfully. Dr. Sushil Bhatia is an experienced entrepreneur, author, consultant, professor and community leader. He holds seven patents to his credit. He has won several awards some of which are mentioned below:

- Small Business of the Year (1997) by Chamber of Commerce

- Sam Walton Business Leader of the Year (1998)

- Economic Development Award (1997) by Chamber of Commerce

- Runner-up Innovation Award (1998) for New "Disruptive Technology"

by Discover magazine

- Massachusetts' Small Businessperson of the Year (2003) by U.S. Small Business Administration

\section{EARLY DAYS}

After completing his initial education in India, he earned Doctor of Science in Chemistry at University de Liege, Belgium specializing in polymers, adhesives, printing methods, labels and inks. He subsequently earned an MBA (Suffolk University, Boston, Massachusetts), specializing in marketing and sales. He wanted to be an entrepreneur right from the beginning and wanted to create an impression in the market place. The expertise gained during the doctoral program provided deeper insights into the domain of polymers. He further built up his domain knowledge through a Post Doc and

Journal of Technology

Management for Growing Economies

Vol. 5 No. 1

April 2014

pp. $81-87$

\section{ChItKARA 司 \\ UNIVERSITY}

(C)2014 by Chitkara University. All Rights Reserved. 

adhesives company. Environmental concerns were gaining ground at that time and environment friendly products were gaining ground in the market place. He worked with MACTAC and then moved to Houston and thereafter to Boston. He had joined Dennison Manufacturing and was responsible for launching several products over the next thirteen years.

\section{EARLY WORK YEARS}

Through a career of over twenty-five years, he has co-developed or invented many products in common use today: Glue Stic, unique convention/seminar name badges, mailing labels, laser/copier labels, binding systems and electrosensitive paper.

He has led new product launch teams for Dennison with IBM and Gillette, and his efforts have led to commercial sales in the hundreds of millions of dollars. He has successfully started a variety of companies in diverse fields - printing, packaging, software, recycling and inks. These companies include:

- JMD Manufacturing - Marking and coding equipment and supplies. Dr. Bhatia is currently President/ CEO of this company

- DeCopier Technologies Inc. - A radically new technology for erasing ink and ink-related images from printed and copied paper, directed toward insuring the security of confidential documents. This earned him widespread write-ups in The Wall Street Journal, The Boston Globe, The Boston Business Journal and various international publications, as well as interviews on $\mathrm{ABC}, \mathrm{NBC}$ and $\mathrm{CNN}$.

- Kriticka - A software company devoted to leveraging Dr. Bhatia's extensive knowledge base in the ink, adhesives, packaging and printing industries

- Control Print India - A joint venture company with Indian entrepreneurs in the product identification and supplies business. The company now has 250 employees, has successfully completed an IPO and currently has sales of over Rs 300 million.

In addition he has started up a manufacturing plant in India and built it into a national distribution business. It was sold in the third year after $100 \%$ per year sales increases.

He also set up a distribution network for a Fortune 200 company in India, China and Hong Kong for its product identification, labeling and packaging products. This resulted in sales of over \$20 million, despite local government restrictions. 


\section{DEVELOPING THE DECOPIER}

At JMD, Sushil developed the decopier technology. The decopier technology involves removing the ink from the paper. So what inspired this idea of developing a decopier? Watching the white waste paper inspired the question in Sushil's mind "What if the users could clean up this paper at their location and then reuse it. Wouldn't that be great?"

This led Sushil to thinking of ink removal and subsequently decopying it since the largest number of white sheets are printed on copier and laser printers. The technology was licensed since it was felt that a company in the similar business will be able to do it more justice in commercializing it. Commercializing requires lot of effort to scale up. A bigger company has more opportunity to do that. The printed paper therefore can be reused and can lead to recycling and reuse of paper. The decopier technology when it was developed in USA, paper was still cheaply available. The technology was then licensed to a Canadian company. Hence in some way, the technology was developed ahead of time.

\section{TECHNOLOGY FOR REMOVING THE TATOOS FROM THE BODY}

The second key technology developed by Sushil is related with removal of tattoos. Lot of people get tattoos on and face a major challenge getting rid of them. This technology enables the removal of the tattoos without any side effects. Since decopier goes inside the paper and breaks up the toner using a thermo chemical process, it was felt that a similar approach could be used for removing tattoo inks which are also embedded deeply in the skin - just as toner is embedded in the paper. After talking to people, it was found that a large number of tattooed people have tattoo regret after a few years of getting tattoos.

Sushil knew the inks, he knew the removal process and felt that the market was large enough for them to explore. There are 70 million people in the U.S. alone who have tattoos and about $25 \%$ of them have tattoo regret.

Once Sushil's company completes all the testing, they will look for a potential licensing partner that has a strong presence in the toiletry and cosmetic industry. As the industry stands now, most of the people who want to get rid of the tattoo believe that most of the current products do not work and they do not trust any company. This was the basis of their thinking process to license the technology to a big company that has credibility in the market place.

Q: Why did you choose these options against other possibilities?

We decided to stay with our core strength of product development and testing. Our advisors also felt that it was the right approach to bring others into

Journal of Technology Management for Growing Economies, Volume 5, Number 1, April 2014
Insights From an

Entrepreneur 

extensive amount of testing in the lab and on humans that a bigger company can handle in a more effective manner.

\section{COMMON LESSONS IN DEVELOPING BOTH THE TECHNOLOGIES}

A few lessons can be shared in developing both the technologies:

- Make sure you develop the product for the customer and not for yourself. Always ask the question "will the dog eat the dog food?". You may have the best product but if the customers do not want it, this is no good.

- In product development and launch, the equation to follow is: $2+2=1 / 2$. First 2 is for time, second 2 is for money and $1 / 2$ is ROI. Simply put: it will take twice as long as we think it would, will costs twice as much as we thought it would and the return will be $1 / 2$ of what we anticipated.

Q: What are the reasons why these technologies were not commercially exploited by JMD itself?

We felt that a bigger company with larger market footprint will be able to commercialize them more successfully. This way we focus on what our strength is i.e. identifying the opportunity and developing new products/technologies.

\section{INSIGHTS INTO NEW PRODUCT DEVELOPMENT FROM AN ENTREPRENEUR}

New product development is a time intensive and a resource intensive process. It takes an enormous amount of effort to take a product from an ideation stage to a commercial launch. It is also a risky process as chances of success are way smaller than chances for failure.

There are several learnings from new product development which Sushil has shared:

1. Unrestricted thinking

There needs to be a barrier free thinking. The obstacles should not be considered at the first stage itself. Lot of options must be generated and then one must focus on specific ideas.

2. Think out of the box

Most of the times, people create boundaries in their thought process. It is very important to observe the phenomenon and see the gaps in the market place. Observing markets and talking to people greatly helps. At a broader level, one must see opportunity where others have not seen it. In this world, the boundaries are no more.

3. Product Failure

In new product development, 80 percent of the new products fail. The 
success comes in from execution and perseverance of the people. There are many ways by which incubation can be initiated. Also one must be concerned about competition. Unless the product is fully developed, ideas must be guarded closely.

4. Patience and Perseverance

Also with new product development, lot of patience and trust in required. In an organizational setting, people give up too quickly. Life never really follows a plan. One has to find a way and go around it. Many of the projects are abandoned at a stage of ideation itself.

The timing of launch of product is also very important. The decline of Nokia and the rapidly changing market dynamics has very rich lessons for bringing in change and embracing innovation at an appropriate time.

5. Open Innovation Approach

One must look at various stakeholders involved in developing a business. There are very valuable insights from various customers specially in the domain of industrial products. A substantial number of new product development are sourced from the key customers. If an entrepreneur just works on his own, he would spend twice the amount of time and would be half as effective as compared to an entrepreneur who is well networked.

6. Over optimism

Whenever, new entrepreneurship happens, entrepreneurs are over optimistic. There are millions of dollars that are projected as revenues. Also people tend to lose focus very quickly as well. Entrepreneurs who are more realistic in the returns and stay focused on the task at hand tend to be more successful.

7. Deployment of Resources

It is very important for the entrepreneurs to keep cash flows going. Even at the time of crisis, the resource deployment must not be plugged out and the business must keep on going. When times are tough, depression may tend to creep in and mind tends to play games. However, entrepreneurs need to manage their mind. The new direction will evolve based on circumstances.

8. Financing

There could be challenges around personal resources. The venture capital firms or angel investors would always like an entrepreneur to put in his personal resources as well. Angel investors always look out for people with a sense of commitment. People must have persistence and also would have watched the team over a period of time. It should not be seen as a weekend venture. The commitment from the entrepreneurial team must be to the tune of 100 percent.
Insights From an Entrepreneur 
Jauhari, V.

9. Marketing

There are several challenges related with marketing that need to be addressed.

- Finding the right customer.

- The customers must stay with you.

- Creating a team and that stays with you.

- Finding the local distributors: It is important to have local distributors who understand the customers. The villages in India have a huge market potential. The hospitals, chemists, wholesellers. There needs to be a grip over the local people.

- Give good discounts- one should not be greedy over the margins.

- Right pricing strategy is very important. Build in margins for all stakeholders. People are many times timid about the pricing. If the product is good, charge a good price for the same.

There are some more aspects that were discussed with Sushil.

Q: What are the limitations that an entrepreneur faces when commercializing his ideas?

Mostly it has to do with resources. Investors and lenders are very wary of getting stuck with the inventory if the product is not successful. They feel that it is difficult to get rid of the inventory or equipment which can be a direct loss.

Q: In the domain of IT there are lot of successes and scaling up being witnessed. What is the reason for the same?

Most of IT is based on human capital and even if the IT product/service does not take off, the company's investment in hardware is minimal (mostly computers which can written off easily).

Q: With product based initiatives there are other challenges that one faces? In you case would you like to elaborate on these?

With lot of manufacturing having shifted to China, the investors/lenders are even more reluctant to invest since they feel it is much cheaper to outsource. This is a challenge constantly faced by the entrepreneurs in physical or non IT product area particularly when it involves expensive new machinery equipment. The same thing applies to prototyping. The cost of doing it has been a big deterrent for product development. Hopefully the new 3-D technology will help alleviate some of these concerns.

\section{PERSONAL VALUES}

At a personal level, Sushil believes in meditation and laughter. Yoga can be 
a great source of bringing in lot of energy. He believes in 'thinking neutral' rather than 'thinking positive'. Sometimes circumstances in life are such that by just staying neutral one is able to achieve much more.

He also propagates that be nice and helpful to everyone. Make sure all parties. It will lead to more success. As Bhagwat Gita says, "For you to win it is not necessary that someone has to lose". Innovate constantly (products, services, daily living, and even relationships and change your life. This is all a part of Karmic Management.

Vinnie Jauhari, Director, Insitute for International Management and Technology, Gurgaon, India. Email: vinnie.jauhari@yahoo.com.
Insights From an Entrepreneur

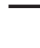

\section{,}

